\title{
LATE FUNCTIONAL AND COSMETIC RESULTS OF TREATMENT OF EYELID TUMOURS* ${ }^{*}$
}

\author{
BY \\ KEITH E. HALNAN + AND M. J. A. BRITTEN§ \\ Christie Hospital and Royal Eye Hospital, Manchester
}

Malignant skin tumours (of basal or squamous cell type) on or near the eyelids may be successfully treated by surgery or by radiotherapy. Both methods inevitably involve excision or irradiation of part of the surrounding or adjacent normal structures; serious consequences of this may not become manifest for many years and valid comparisons between the two methods are therefore difficult to make. If well executed, both radiotherapy and surgery can now be accepted as capable of curing virtually all early tumours, and evaluation of the better method needs assessment more of the undesirable sequelae or cost of cure rather than of only the cure-rate itself.

The techniques both of radiotherapy and of plastic surgery have advanced considerably, and the results of earlier reports are therefore not necessarily relevant to modern methods of treatment. Stetson and Schultz (1949) and Whiting (1951), however, found no significant difference between the results of surgical and radiation treatment; and these, together with earlier reports, emphasize the dangers of inadequate protection of the eyes from harmful doses of irradiation, and of excising too little of the structures surrounding a tumour in an attempt to conserve normal eyelid tissue.

The results of more recent series are summarized in Table I (overleaf); although later papers mention some of the complications arising from the treatment, they are neither detailed nor related to the size of the tumour. Authoritative ophthalmologists have often criticized heavily the results of radiotherapy; for instance, Duke-Elder (1952) wrote: "excision .... is preferable owing to the ultimate uncertainty of radiation and its possible complications which include ectropions, leucoplakia of the conjunctiva, keratitis and necrosis of the cornea, irido-cyclitis and secondary glaucoma, cataract, radio-dermatitis, and interminable osseous radio-necrosis. Excision should, therefore, be the rule, radiation the exception". In Manchester, however, large numbers of cases have been, and continue to be, treated by radiotherapy, and it therefore seemed worthwhile to examine in detail the late results in a substantial number of patients. We have therefore examined 104 patients (in 1964) treated for 71 tumours in 1957-8 and for 35 tumours in 1952-3.

* Received for publication October $18,1966$.

† Address for reprints: Dr. K. E. Halnan, Glasgow Institute for Radiotherapy, Western Infirmary, Glasgow, W.1.

Now at Glasgow Institute for Radiotherapy, Royal and Western Infirmaries, Glasgow.

$\S$ Now at Stockport Infirmary. 
Results OBt

\begin{tabular}{|c|c|c|c|c|c|c|c|c|}
\hline \multirow[t]{2}{*}{ Authors } & \multirow[t]{2}{*}{ Date } & \multirow{2}{*}{$\begin{array}{c}\text { Duration } \\
\text { of } \\
\text { Treatment } \\
\text { (yrs) }\end{array}$} & \multicolumn{2}{|c|}{$\begin{array}{l}\text { Duration of } \\
\text { Follow-up } \\
\text { (yrs) }\end{array}$} & \multirow{2}{*}{$\begin{array}{l}\text { Size of } \\
\text { Tumours } \\
\text { Indicated }\end{array}$} & \multirow{2}{*}{$\begin{array}{l}\text { Principal } \\
\text { Method of } \\
\text { Treatment }\end{array}$} & \multirow{2}{*}{$\begin{array}{c}\text { Number } \\
\text { of } \\
\text { Tumours } \\
\text { Treated }\end{array}$} & \multirow{2}{*}{ 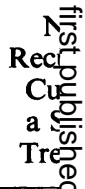 } \\
\hline & & & Max. & Min. & & & & \\
\hline Birge & 1938 & $\begin{array}{l}\text { Up to } \\
1938\end{array}$ & 15 & - & No & $\begin{array}{l}\text { Surgery or } \\
\text { Surgery }+ \\
\text { Radiotherapy }\end{array}$ & 209 & . \\
\hline Martin & 1939 & $1925-1935$ & - & - & No & Mainly $x$ ray & 147 & $\begin{array}{l}\omega \\
\text { o } \\
\text { 응. }\end{array}$ \\
\hline Driver and Cole & 1939 & 1915-1939 & 10 & $\frac{1}{2}$ & No & $\begin{array}{l}\text { Mainly } \\
\text { radiotherapy }\end{array}$ & 193 & $\stackrel{N}{-1}$ \\
\hline Charteris & 1940 & $1930-1935$ & 8 & 3 & No & Radium & 76 & o \\
\hline Smithers & 1940 & $1936-1940$ & 3 & $\frac{1}{4}$ & No & $X$ ray & 39 & Dٕ \\
\hline Hunt & 1947 & $1930-1946$ & - & - & No & Mainly $x$ ray & 100 & $\begin{array}{l}\vec{\varphi} \\
\stackrel{\infty}{\infty}\end{array}$ \\
\hline \multirow[t]{2}{*}{ Stetson and Schultz } & \multirow[t]{2}{*}{1949} & \multirow[t]{2}{*}{ 1933-1944 } & \multirow[t]{2}{*}{-} & \multirow[t]{2}{*}{3} & \multirow[t]{2}{*}{ No } & Mainly $x$ ray & 162 & $\sum_{\substack{0\\
}}^{\circ}$ \\
\hline & & & & & & Surgery & 57 & 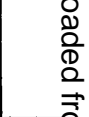 \\
\hline del Regato & 1949 & 1940-1945 & 8 & 3 & No & $X$ ray & 117 & $\begin{array}{l}3 \\
\frac{2}{2} \\
\frac{0}{0}\end{array}$ \\
\hline \multirow[t]{2}{*}{ Whiting } & \multirow[t]{2}{*}{1951} & \multirow[t]{2}{*}{$1925-1938$} & \multirow[t]{2}{*}{-} & \multirow[t]{2}{*}{10} & \multirow[t]{2}{*}{ Yes } & Radiotherapy & 82 & 흥. \\
\hline & & & & & & Surgery & 51 & $\stackrel{2}{3}$ \\
\hline Baclesse and Dollfus & 1960 & $1937-1953$ & - & 5 & Yes & $X$ ray & 556 & $\begin{array}{l}\frac{8}{3} \\
\frac{2}{3}\end{array}$ \\
\hline Fayos and Wildermuth & 1962 & 1939-1956 & - & 3 & Yes & $X$ ray & 90 & 票. \\
\hline Shulman & 1962 & $1950-1960$ & 10 & - & No & Surgery & 195 & $\begin{array}{l}\text { N } \\
\text { W } \\
\text { O } \\
0 \\
0 \\
\text { C }\end{array}$ \\
\hline $\begin{array}{l}\text { McKenna and } \\
\text { Macdonald }\end{array}$ & 1962 & $1943-1958$ & 15 & 5 & No & $X$ ray & 146 & 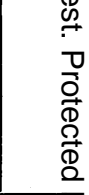 \\
\hline
\end{tabular}


SERIES

\begin{tabular}{|c|c|c|c|}
\hline $\begin{array}{l}\text { of } \\
\text { ences } \\
\text { r a } \\
\text { ind } \\
\text { nent }\end{array}$ & $\begin{array}{l}\text { Nos. of } \\
\text { Deaths due } \\
\text { to the } \\
\text { Tumour }\end{array}$ & $\begin{array}{l}\text { No. of } \\
\text { Radiation } \\
\text { Cataracts }\end{array}$ & Complications and Comments \\
\hline- & 30 & - & $\begin{array}{l}\text { There were thirty deaths and } 106 \text { had either an exenteration or } \\
\text { evisceration or went blind in the affected eye. Local recurrence } \\
\text { rate and complications were not detailed. }\end{array}$ \\
\hline ) & 9 & - & $\begin{array}{l}\text { The possibility of complications from radiotherapy are discussed; } \\
\text { no figures are given. }\end{array}$ \\
\hline- & - & - & $\begin{array}{l}\text { Many of the cases had been treated previously; no details of the } \\
\text { recurrences or of the complications are given. }\end{array}$ \\
\hline 2 & - & 4 & $\begin{array}{l}\text { In four cases the eye on the affected side was blinded, and in } \\
\text { three others the sight was decreased by either corneal ulcera- } \\
\text { tion or cataracts. }\end{array}$ \\
\hline- & - & - & One eye was lost through intra-ocular infection. \\
\hline 1 & 4 & 5 & $\begin{array}{l}\text { The advantages of } x \text { ray over radium discussed. Follow-up } \\
\text { incomplete. }\end{array}$ \\
\hline- & 4 & $\mathbf{0}$ & $\begin{array}{l}\text { Three severe lid deformities followed large tumours, epiphora } \\
\text { followed in eight cases and persistent conjunctivitis in another. }\end{array}$ \\
\hline- & 1 & - & $\begin{array}{l}\text { One case developed ptosis after operation and in another the } \\
\text { cosmetic result was poor. Results from surgical or radiation } \\
\text { treatment not significantly different. }\end{array}$ \\
\hline- & - & - & $\begin{array}{l}\text { Two cases developed delayed necrosis, two epiphora, and one } \\
\text { persistent pain. }\end{array}$ \\
\hline- & - & - & \multirow{2}{*}{$\begin{array}{l}\text { Two eyes had to be enucleated owing to secondary glaucoma. } \\
\text { Tumours over } 1 \text { " in diameter were found to be more likely to } \\
\text { recur whatever method of treatment had been used. }\end{array}$} \\
\hline 4 & 3 & - & \\
\hline 4 & - & $\begin{array}{l}\text { approx. } \\
1 \text { per cent. }\end{array}$ & $\begin{array}{l}\text { A higher recurrence rate after larger tumours was noted, there } \\
\text { was no assessment of the cosmetic result and less than } 1 \text { per } \\
\text { cent. developed secondary glaucoma. }\end{array}$ \\
\hline 2 & 2 & 0 & $\begin{array}{l}\text { The size of the tumours is given, but it is not related to the } \\
\text { results; thirteen cases developed epiphora, three delayed } \\
\text { necrosis, and three lid deformity. }\end{array}$ \\
\hline 6 & 3 & - & $\begin{array}{l}\text { Treatment included enucleation in } 22 \text { cases. Two cases developed } \\
\text { severe epiphora, nine lid deformity, two persistent conjuncti- } \\
\text { vitis, and five cosmetic defects. Of } 231 \text { cases biopsied only the } \\
195 \text { treated were found to have malignant tumours. }\end{array}$ \\
\hline 3 & - & $\mathbf{0}$ & $\begin{array}{l}\text { Cosmetic results were excellent apart from three with telangiec- } \\
\text { tases, the only other complications were one glaucoma and one } \\
\text { ectropion. There was no correlation between the failure to } \\
\text { control the tumour in three cases and either the size or histo- } \\
\text { pathy of the tumour. }\end{array}$ \\
\hline
\end{tabular}




\section{Investigation and Methods}

The object of this survey was not so much the usual complete follow-up of a group of patients to assess whether there was cure of the treated tumour, or at its simplest whether the patient was alive or dead, but an attempt to assess the frequency of such alleged serious hazards of radiotherapy to the eyes and eyelids as functional defects, deformity, keratitis, necrosis, irido-cyclitis, and cataract. For this assessment to be comprehensive, it was necessary for the patients concerned to be in reasonable general health, so as to be able to come to the Outpatient Department of the Manchester Royal Eye Hospital to be fully examined jointly by an ophthalmologist and a radiotherapist. It was accepted that, with adequate follow-up and further surgery or radiotherapy if needed for recurrence, virtually all squamous and basal cell carcinomata of the eyelids should be cured.

Radiation sequelae may take many years to develop fully; it was therefore decided to examine patients treated 5 to 7 and 10 to 12 years earlier. During 1952-3 and 1957-8 about 700 patients were treated at the Christie Hospital for squamous or basal cell carcinoma on, or adjacent to, the eyelids. Preliminary questionnaires were sent to the 181 of these who were aged under 70 years in 1964 and who were thought to be still living in or near Manchester. 104 of these patients were then seen; the remainder were either dead, or had moved away from Manchester, or were too ill to come to hospital.

A full ophthalmological examination of both eyes was made, and the treatment area was checked by a radiotherapist; a colour photograph was taken for later assessment and comparison of the cosmetic result, and the mobility and function of the eyelids were noted. In all cases refraction and accurate sight testing, slit-lamp microscopy of the anterior segment and lens with the pupil widely dilated, fundus examination, and syringing of the lacrimal passages were carried out; tear secretion was assessed by Schirmer's test in cases in which the lacrimal gland might have received a significant dose of radiation. 58 tumours had been treated by $x$ ray therapy, 38 by radon gold seed implant, and eighteen by surgical excision (eight after radiotherapy).

\section{Radiation Techniques}

Full records were available of the radiation methods used. The standard radiographs had been kept of all implants, taken with a brass ring of known diameter, at a large focusfilm distance (of 36 to 40 in.) and in true postero-anterior and lateral planes.

In 1952-3 and 1957-8, superficial $x$-ray therapy for these cases was always at a half-value layer of $3 \mathrm{~mm}$. aluminium (140 K.V., $2 \mathrm{~mm}$. aluminium filter) and with lead shields over the cornea of thickness $1 \mathrm{~mm}$., which therefore transmitted about 0.7 per cent. of the radiation given.

Radon gold seed implants were of two kinds, "threaded"- - using threaded gold seeds which were removed after about 7 days, when the desired dose had been given-or "ordinary"- - using permanently implanted gold seeds. The activity of the seeds used had been recorded and implants were of the "single plane" type, calculated to give a dose at $0.5 \mathrm{~cm}$. of from 5,500 to $7,500 \mathrm{r}$ (actual doses varying more widely from 4,000 to 8,750 r).

\section{Results}

In two cases the tumours were bilateral so that 106 were examined in the 104 patients. All tumours had been within $20 \mathrm{~mm}$. of the eyelid margin. There were seventeen squamous cell carcinomata confirmed by histological section; the remainder were all thought to be basal cell carcinomata, although many with typical clinical appearances were not examined microscopically. Apart from nine local recurrences after simple surgical excision at other hospitals, none had been previously treated; Table II (opposite) shows the sites of the tumours. 
TABLE II

Sites OF 106 Tumours

\begin{tabular}{l|c|c|c}
\hline \multicolumn{1}{c|}{ Tumour } & $\begin{array}{c}\text { Basal Cell } \\
\text { Cancer }\end{array}$ & $\begin{array}{c}\text { Squamous Cell } \\
\text { Cancer }\end{array}$ & Total \\
\hline Inner canthus & 43 & 6 & 49 \\
Lower lid & 36 & 4 & 40 \\
Upper lid & 6 & 7 & 13 \\
Outer canthus & 4 & 0 & 4 \\
\hline Total & 89 & 17 & 106 \\
\hline
\end{tabular}

It was impossible to assess from the notes the exact size of the tumours before treatment, but this could be deduced in those treated by radiotherapy from the size of the treated area. Each tumour had not less than $0.5 \mathrm{~cm}$. of clinically normal tissue treated on either side of its maximum diameter, and a treatment area of $2.5 \mathrm{~cm}$. would therefore have contained a tumour of between 1 and $1.5 \mathrm{~cm}$. in diameter.

The cosmetic appearance of the treated area was assessed by both authors at the time of examination and again later, using the coloured photographs taken at the time of the followup examination. Each case was placed in one of the following grades:

(1) Negligible changes.

(2) Sequelae obvious, but tolerable.

(3) Severe changes or unsightly appearance.

An example of each grade is shown in Fig. 1 (below and overleaf).

(a)

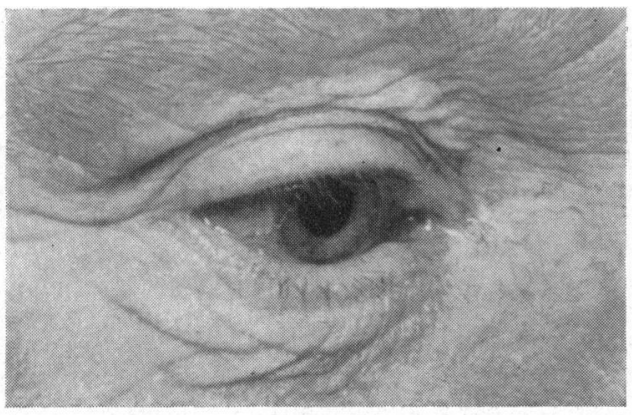

(c)

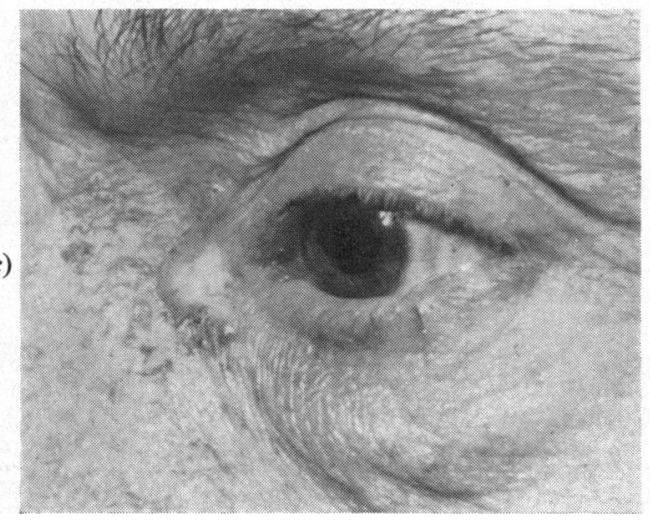

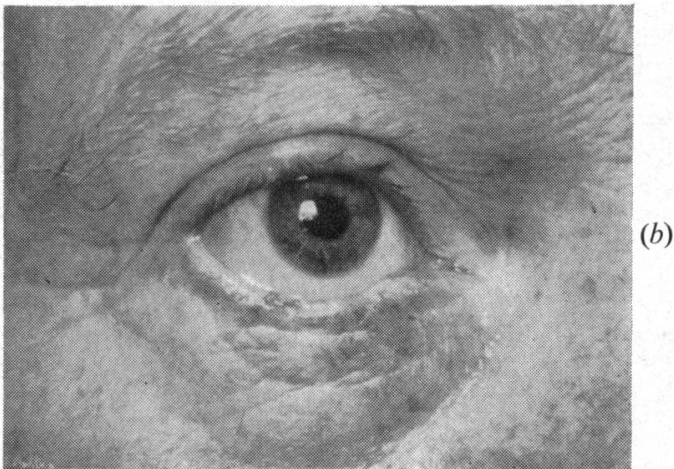

Fig. 1.-Examples of changes visible in 1964 after treatment for eyelid tumours.

Grade 1: Negligible-basal cell carcinoma at the inner canthus treated by $x$-ray therapy in $1958(a)$.

Grade 2: Obvious but tolerable-(b) basal cell carcinoma on right lower lid treated by $x$-ray therapy in 1957, (c) basal cell carcinoma at left inner canthus treated by radon seed implant in 1957. 

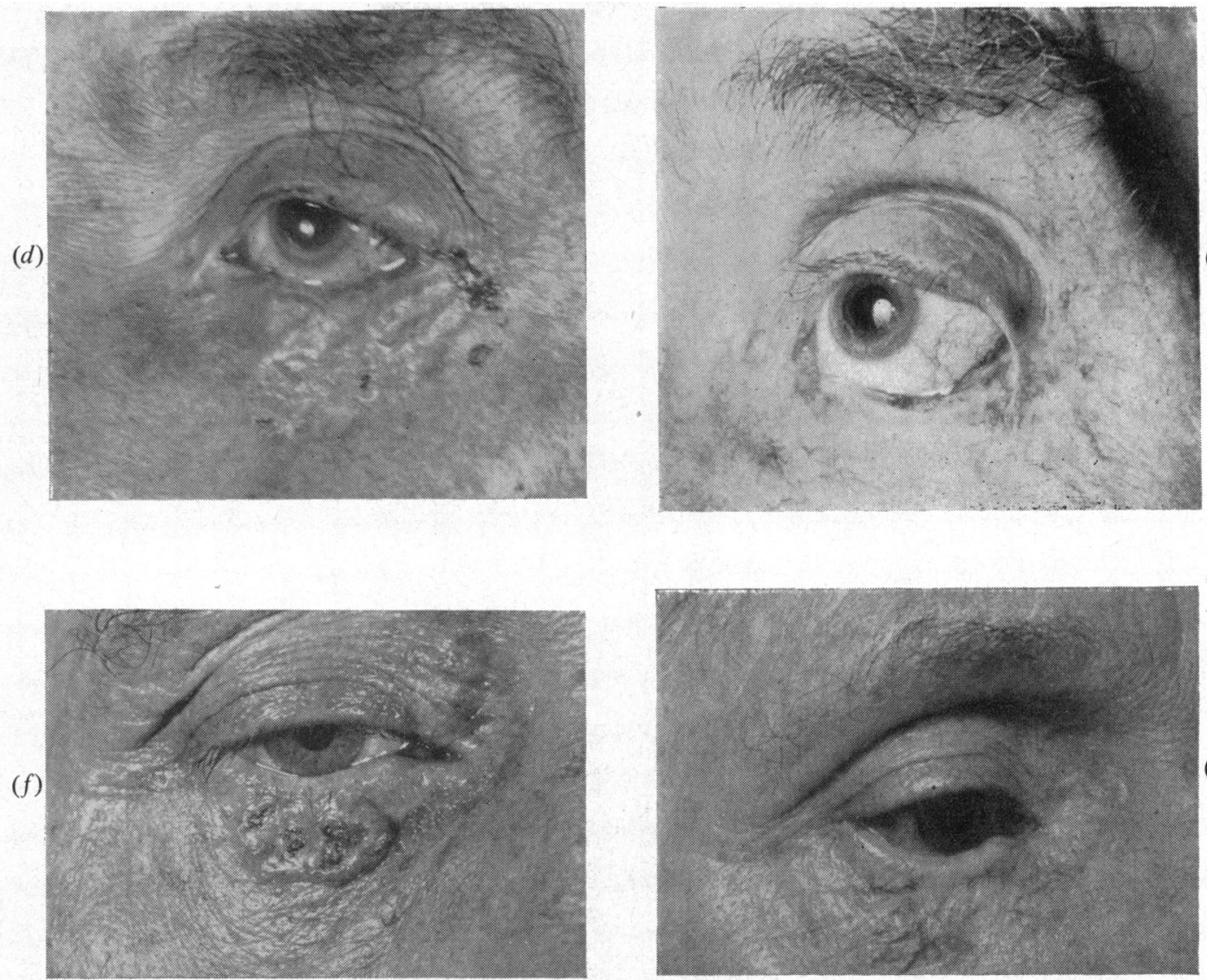

FiG. 1.-Examples of changes visible after treatment.

Grade 3: Severe or unsightly $-(d, e)$ basal cell carcinoma on left lower lid treated by $x$-ray therapy in 1958, $(f, g)$ basal cell carcinoma on right lower lid treated by $x$-ray therapy in 1958 .

In Fig. 2 (opposite) the method of treatment and the size of the treated area are related to the ultimate cosmetic result. The eight local recurrences were all basal cell carcinomata, four at the inner canthus, two on the upper lid, and one each at the outer canthus and on the lower lid. Except for two during the second year and another during the fifth, all recurred before the end of the first year after treatment: four after $x$-ray therapy and four after radon gold seed implants.

The complications after treatment are summarized in Table III (opposite). Minor complaints included occasional irritation of the scar in hot weather, intermittent slight blepharitis, and slight discomfort from the weight of spectacles resting on the scar; the remaining complications are detailed in the Table. Conjunctivitis did not last for longer than a year at the most, and only three patients with considerable irritation of the scar experienced this after the first 2 years; this group of three consisted of two treated with radon gold seed implants who suffered recurrent attacks of troublesome itchiness and dryness, and one other who had recurrent trichiasis and entropion following primary excision repaired by a pedicle graft. The five cases of delayed necrosis following $x$-ray therapy all healed within 2 months and suffered no recurrences. 


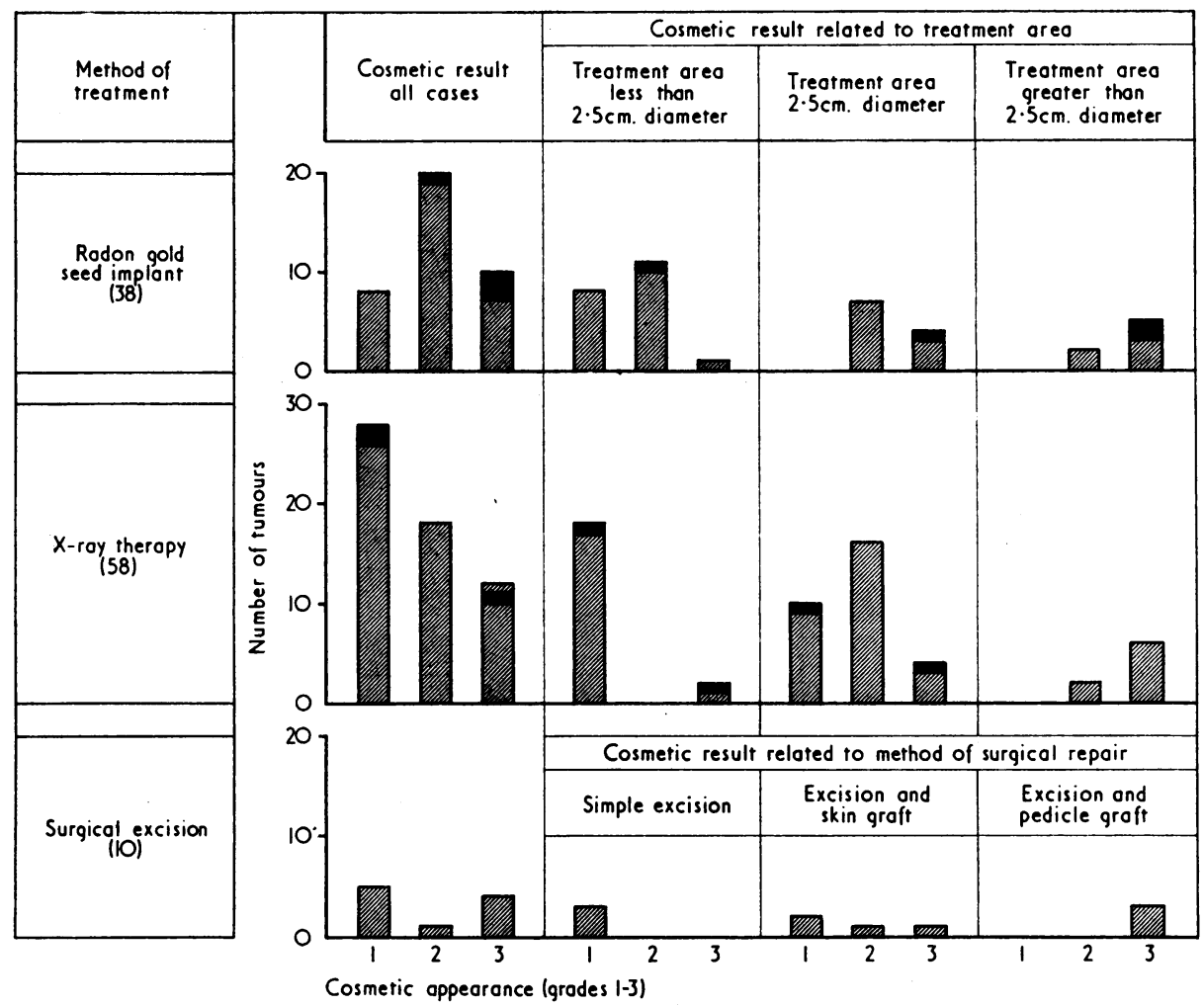

FIG. 2.-Method of treatment related to grade of cosmetic result and size of area irradiated.

TABLE III

Complications of TReatment

\begin{tabular}{|c|c|c|c|c|c|c|c|c|c|c|c|c|c|}
\hline \multirow{2}{*}{$\begin{array}{c}\text { Method } \\
\begin{array}{l}\text { Size of Treatment Area } \\
\text { (cm. diam.) }\end{array}\end{array}$} & \multicolumn{3}{|c|}{$\begin{array}{c}X \text { rays } \\
\text { Only }\end{array}$} & \multicolumn{3}{|c|}{$\begin{array}{l}X \text { rays with } \\
\text { Surgical } \\
\text { Incision for } \\
\text { Recurrence }\end{array}$} & \multicolumn{3}{|c|}{$\begin{array}{c}\text { Gold Seed } \\
\text { Implant } \\
\text { Only }\end{array}$} & \multicolumn{3}{|c|}{$\begin{array}{c}\text { Gold Seed } \\
\text { Implant with } \\
\text { Surgical Incision } \\
\text { for Recurrence }\end{array}$} & \multirow{2}{*}{$\begin{array}{c}\text { Surgical } \\
\text { Excision } \\
\text { Only }\end{array}$} \\
\hline & $<2.5$ & $2 \cdot 5$ & $>2.5$ & $<2.5$ & $2 \cdot 5$ & $>2 \cdot 5$ & $<2 \cdot 5$ & $2 \cdot 5$ & $>2.5$ & $<2.5$ & $2 \cdot 5$ & $>2.5$ & \\
\hline Total No. Treated & 18 & 28 & 8 & 2 & 2 & $\mathbf{0}$ & 20 & 10 & 4 & 1 & 1 & 2 & 10 \\
\hline $\begin{array}{l}\text { Minor Irritation of Scar } \\
\text { Lid Margin Notched }\end{array}$ & 1 & $\begin{array}{l}4 \\
1 \\
\end{array}$ & $\overline{1}$ & $\overline{-}$ & 二 & 二 & 5 & 4 & 1 & $\overline{-}$ & 二 & 1 & 2 \\
\hline $\begin{array}{l}\text { Delayed Necrosis Inflammation } \\
\text { Extrusion of Gold Seed }\end{array}$ & 2 & 2 & 1 & 1 & - & - & 8 & 7 & 1 & - & - & 1 & - \\
\hline Persistent Conjunctivitis & 一 & 1 & 1 & - & - & - & 1 & - & 1 & - & - & - & - \\
\hline Marked Irritation of Scar & 2 & 4 & 3 & 1 & - & - & 5 & - & - & - & - & 2 & 1 \\
\hline $\begin{array}{l}\text { Ectropion, Entropion, Loss of } \\
\text { Lid Substance }\end{array}$ & - & 3 & 2 & 一 & - & - & 1 & - & 1 & - & 1 & - & 1 \\
\hline Troublesome Epiphora & 4 & 5 & - & - & - & - & 5 & - & 1 & - & 1 & 1 & - \\
\hline Radiation Cataract & - & - & - & - & $1 \dagger$ & - & 6 & 4 & 2 & - & - & 2 & - \\
\hline Grade 3 Cosmetic Result & 1 & 3 & 6 & $1^{*}$ & 1 & - & 1 & 2 & 3 & - & 1 & 2 & 4 \\
\hline No Major & 11 & 19 & 2 & - & - & - & 6 & - & - & - & - & - & 6 \\
\hline None & 10 & 14 & 2 & - & - & - & 4 & - & - & - & - & - & 4 \\
\hline
\end{tabular}

* Hypopyon ulcer found at first dressing after excision of recurrent tumour

+ Conjunctival and scleral ulceration due to exposure of the eye after $x$-ray therapy necessitated a free skin graft to the upper eyelid for shortage of tissue; rapid healing with no resultant loss of sight followed. 
The incidence of blockage of the lacrimal passages and of epiphora (Table IV) was high, as might be expected in a series containing 72 tumours sited either medial to the inner canthus or on the medial half of the lower lid. Those who complained spontaneously or were obviously inconvenienced are recorded in Tables III and IV as having "troublesome epiphora"; the remainder either had no complaint or were not inconvenienced by the occasional epiphora, which occurred most often only in cold and windy conditions. Some of the patients with epiphora had patent lacrimal passages on syringing, but the lower

TABLE IV

INCIDENCE OF EPIPHORA AND OF BLOCKAGE OF LaCrimal Passages after Treatment

\begin{tabular}{|c|c|c|c|}
\hline & Tumour & No. & Per cent. \\
\hline \multicolumn{2}{|c|}{$\begin{array}{c}\text { Situated near inner canthus or on medial } \\
\text { half of lower lid }\end{array}$} & 72 & \\
\hline Complaint & $\begin{array}{l}\text { Blocked lacrimal passages } \\
\text { "Troublesome" epiphora } \\
\text { Occasional epiphora }\end{array}$ & $\begin{array}{l}43 \\
17 \\
30\end{array}$ & $\begin{array}{l}60 \\
24 \\
42\end{array}$ \\
\hline
\end{tabular}

(Idiopathic occlusion of the lacrimal passages on the opposite side to the tumour occurred in seven cases, four of whom had epiphora from this eye)

canaliculi were hard and rigid because of surrounding fibrosis; many with lacrimal obstruction had little or no epiphora. This latter state was found to be not uncommon by Dalgleish (1964) in his review of the incidence of idiopathic acquired lacrimal obstruction.

Deformity of the lid margin after primary treatment required surgical correction in the case detailed at the foot of Table III, and radiation cataracts (mostly minor and not affecting vision) were confined to the same side as the tumour and to the group treated by radon gold seed implants except for a single case treated with $x$-ray therapy; here failure to shield the left eye in a case of tumour at the right inner canthus resulted in a sector-shaped radiation cataract of the medial part of the left lens. Further details of the radiation cataracts are given in Table V (opposite); a full report on their topography and occurrence in relation to the radiation dosage to the lens has been published separately (Britten, Halnan, and Meredith, 1966).

No painful scars, persistent keratitis, defective tear secretion, bone necrosis, or examples of retinal damage were found, and only the one case which developed an hypopyon ulcer after surgical excision showed iris changes (Table III).

\section{Discussion}

The results from the 58 cases treated with $x$-ray therapy were highly satisfactory, and only the patient with corneal ulceration following surgical excision of a recurrent tumour suffered any diminution or loss of sight (Table III). Shielding the eye from harmful doses of $x$ rays appeared to have been completely successful and the only radiation cataract found in this group occurred in an unshielded contralateral eye. In this series the four 
TABLE V

(from Britten, Halnan, and Meredith, 1966)

Radiation CataRACTS (OBSERVED in 1964)

\begin{tabular}{|c|c|c|c|c|c|c|c|c|}
\hline \multirow{2}{*}{ Therapy } & \multirow{2}{*}{$\begin{array}{c}\text { Case } \\
\text { Number }\end{array}$} & \multirow{2}{*}{$\begin{array}{l}\text { Extent of } \\
\text { Cataract }\end{array}$} & \multicolumn{2}{|c|}{ Visual Acuity } & \multirow{2}{*}{$\begin{array}{l}\text { Radiation } \\
\text { Dose to } \\
\text { Tumour }\end{array}$} & \multirow{2}{*}{$\begin{array}{c}\text { Mean Diameter } \\
\text { of Implant or } \\
x \text {-ray Field } \\
\text { (cm.) }\end{array}$} & \multirow{2}{*}{$\begin{array}{l}\text { Year } \\
\text { Treated }\end{array}$} & \multirow{2}{*}{$\begin{array}{c}\text { Years after } \\
\text { Treatment } \\
\text { when noticed } \\
\text { by Patient }\end{array}$} \\
\hline & & & Treated & Untreated & & & & \\
\hline $\begin{array}{l}X \text { ray (Cataract in } \\
\text { Untreated Eye) }\end{array}$ & 34 & Sector & $6 / 4$ & $6 / 4$ & $2250 r$ & $3 \cdot 0$ & 1954 & - \\
\hline $\begin{array}{l}\text { Threaded Radon Gold } \\
\text { Seed Implant }\end{array}$ & $\begin{array}{r}69 \\
102 \\
\end{array}$ & $\begin{array}{l}\text { Whole lens } \\
\text { Sector }\end{array}$ & $\begin{array}{l}\text { P.L. } \\
6 / 18\end{array}$ & $\begin{array}{l}6 / 5 \\
6 / 5 \\
\end{array}$ & $\begin{array}{l}5950 \mathrm{r} \\
6000 \mathrm{r}\end{array}$ & $\begin{array}{l}2.75 \\
2.0\end{array}$ & $\begin{array}{l}1953 \\
1953 \\
\end{array}$ & $\frac{7}{-}$ \\
\hline $\begin{array}{l}\text { Permanent Radon Gold } \\
\text { Seed Implant }\end{array}$ & $\begin{array}{l}21 \\
25 \\
51 \\
70 \\
72 \\
75 \\
76 \\
82 \\
87 \\
93 \\
95 \\
97\end{array}$ & $\begin{array}{l}\text { Sector } \\
\text { Sector } \\
\text { Sector } \\
\text { Sector } \\
\text { Sector } \\
\text { Sector } \\
\text { Sector } \\
\text { Sector } \\
2 / 3 \text { of lens } \\
\text { Whole lens } \\
\text { Whole lens } \\
\text { Whole lens }\end{array}$ & $\begin{array}{l}6 / 6 \\
6 / 5 \\
6 / 18^{*} \\
6 / 9 \\
6 / 6 \\
6 / 5 \\
6 / 6 \\
6 / 9 \\
5 / 60 \\
\text { CF } \\
\text { PL } \\
6 / 5+\end{array}$ & $\begin{array}{l}6 / 6 \\
6 / 5 \\
6 / 60^{*} \\
6 / 9 \\
6 / 6 \\
6 / 4 \\
6 / 6 \\
6 / 5 \\
6 / 5 \\
6 / 5 \\
6 / 9 \\
6 / 5\end{array}$ & $\begin{array}{l}5270 \mathrm{r} \\
5550 \mathrm{r} \\
6450 \mathrm{r} \\
6000 \mathrm{r} \\
6000 \mathrm{r} \\
5550 \mathrm{r} \\
6500 \mathrm{r} \\
5500 \mathrm{r} \\
6500 \mathrm{r} \\
6750 \mathrm{r} \\
5460 \mathrm{r} \\
6500 \mathrm{r}\end{array}$ & $\begin{array}{l}1 \cdot 8 \\
3.0 \\
2 \cdot 0 \\
2 \cdot 0 \\
2 \cdot 0 \\
2 \cdot 25 \\
2 \cdot 5 \\
2 \cdot 5 \\
2 \cdot 5 \\
3 \cdot 0 \\
3 \cdot 25 \\
2 \cdot 5\end{array}$ & $\begin{array}{l}1958 \\
1958 \\
1957 \\
1952 \\
1953 \\
1953 \\
1953 \\
1952 \\
1953 \\
1952 \\
1952 \\
1952\end{array}$ & $\begin{array}{l}= \\
= \\
\bar{z} \\
\bar{z} \\
\overline{1} \\
11 \\
10 \\
13\end{array}$ \\
\hline
\end{tabular}

* Both eyes highly myopic, radiation cataract unlikely to be a significant cause of lowered visual acuity

+ With contact lens after extraction C.F.-counts fingers only P.L. - perception of light only

local recurrences followed small tumours, since the size of the treatment ateas which contained them was $2.5 \mathrm{~cm}$. in diameter in two instances, and less than this in the other two; their surgical removal was successful and uneventful apart from the ocular complications referred to above and at the foot of Table III.

At the foot of Table III are also given details of the only case requiring operation for lid deformity, and apart from nine patients with troublesome epiphora and an isolated case of delayed necrosis during the third year, no complications occurred or persisted after the first 2 years following treatment. As expected, the cosmetic results were closely related to the size of the treatment areas, and six of the twelve unsightly or severe scars followed treatment to an area in excess of $2.5 \mathrm{~cm}$. in diameter, whilst treatment of the smaller areas gave excellent results.

The necessity for shielding the lens was borne out by the relatively high incidence of radiation cataract following treatment by radon gold'seed implant, where shielding of the eye is impossible; these and the more frequent occurrence of other complications emphasize the unsuitability of this method of treatment in this site. The numbers treated surgically were too small for any firm conclusions to be drawn, but at least they show that the functional or cosmetic results of surgery may in individual cases be as unsightly or as severe as from radiotherapy, sometimes more so.

\section{Conclusions}

It seems reasonable to deduce that surgery (by simple excision) and radiotherapy (usually by superficial $x$-ray treatment) can give extremely good results both immediate and late for small tumours. Larger tumours, of more than $1 \mathrm{~cm}$. in diameter, will often require a skin or pedicle graft after excision, or a larger area treated by irradiation, so that the final result may sometimes be unsightly or troublesome after either method. Selection of treatment, therefore, should be based on the age and general health of the patient-taking into account the probable expectation of life and fitness for general anaesthesia-as well as 
on the size and site of the tumour. One important consideration can be occupation; it is often preferable to treat an out-door worker by surgery, since persistent exposure to sun and/or inclement weather can lead to a higher incidence of unpleasant radiation skin changes, even to temporary necrosis. On the other hand, an elderly frail patient will usually be much better treated by radiotherapy given as an out-patient procedure.

Comparison of results shows that $x$-ray therapy gives much better results than radon gold seed implants, mainly because of the possibility of adequately shielding the eye (especially the lens). (In fact radon gold seed implants near the eye had already been given up in Manchester, except for special cases). The late cosmetic and functional results strongly suggest that the minimum safe area should be irradiated, taking a margin of normal tissue of say at least $5 \mathrm{~mm}$. and up to $10 \mathrm{~mm}$. wide all round the visible tumour. Radiation cataract does not appear to be a significant hazard after superficial $x$-ray therapy when the normal eye-shields are used. Finally, it should be mentioned that obviously inoperable late cases can often be treated with remarkable success by $x$-ray therapy (Fig. 3 ).
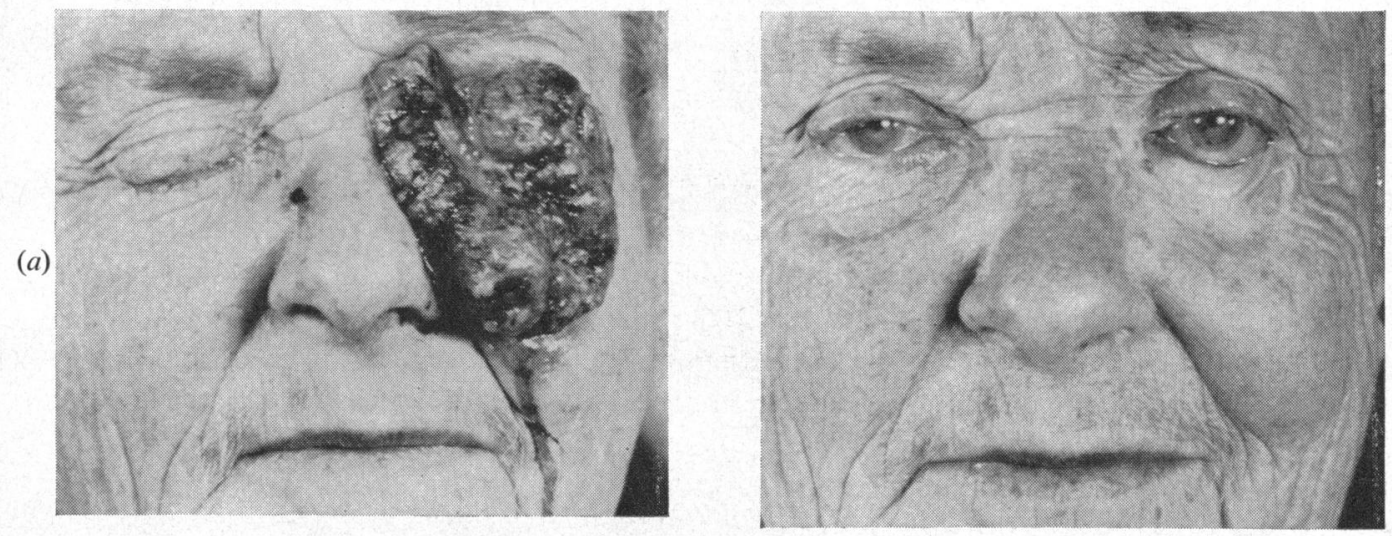

FIG. 3.-Advanced basal cell carcinoma of left inner canthus before (a) and after $(b) x$-ray therapy in 1953. (This patient died of another cause in 1964 and has not been included in the series reviewed.)

\section{Summary}

A detailed follow-up examination was made in 1964 of the eyes of seventy patients treated in 1957-8 and of 34 patients treated in 1952-3 for skin tumours on or near the eyelids.

The results of $x$-ray therapy were extremely good, but there was a substantial incidence of radiation cataract after radon gold seed implant. Radiation stigmata or surgical scarring was negligible after treatment of most small tumours, the incidence of obvious or unsightly changes being related to the size of larger tumours. Blocked lacrimal passages and consequent epiphora occurred in many patients, but was troublesome only to a minority. Deformity of the lid margin was serious in only one patient, and no cases were seen of continued pain, persistent keratitis, defective tear secretion, retinal damage, bone necrosis, or irido-cyclitis caused by radiotherapy.

Suggestions are made regarding the choice of treatment in individual cases.

We are very grateful to the many colleagues who referred these patients for treatment, and who assisted in their care and in this investigation, and particularly to Dr. O. M. Duthie. 


\section{REFERENCES}

BaClesse, F., and Dollfus, M. A. (1960). Arch. ophtal., n.s. 20, 473.

Birge, H. L. (1938). Arch. Ophthal. (Chicago), 19, 700; 20, 254.

Britten, M. J. A., Halnan, K. E., and Meredith, W. J. (1966). Brit. J. Radiol., 39, 612.

Charteris, A. A. (1940). Amer. J. Roentgenol., 44, 737.

Dalgleish, R. (1964). Brit. J. Ophthal., 48, 373.

Driver, J. R., and Cole, H. N. (1939). Amer. J. Roentgenol., 41, 617.

Duke-Elder, S. (1952). "Text-book of Ophthalmology", vol. 5, p. 5049. Kimpton, London.

Fayos, J. V., and Wildermuth, O. (1962). Arch. Ophthal. (Chicago), 67, 298.

HuNT, H. B. (1947). Amer. J. Roentgenol., 57, 160.

McKenna, R. J., and Macdonald, I. (1962). Calif. Med., 96, 184.

MarTin, H. E. (1939). Arch. Ophthal. (Chicago), $22,1$.

Regato, J. A. DEL (1949). Radiology, 52, 564.

Shulman, J. (1962). Brit. J. plast. Surg., 15, 37.

Smithers, D. W. (1940). Brit. J. Ophthal., 24, 105.

Stetson, C. G., and Schulz, M. D. (1949). New Engl. J. Med., 241, 725.

Whiting, M. H. (1951). Trans. ophthal. Soc. U.K., 71, 3. 